Page 1 of 1

1. EDT No 141643
2. To: (Receiving Organization) Distribution

5. Proj./Prog./Dept./Div.: Waste Management

8. Originator Remarks:

\section{APPROVAL/RELEASE}

11. Receiver Remarks:
6. Cog. Engr.: JH Busse11

$+2$

\section{From: (Originating Organization) Inst. E Control}

(2)

4. Related EDT MO.:
NIA
7. Purchase Order No.:
N/A

9. Equip./Component Mo.: NIA

10. System/Bldg./Facility:

$$
\text { 241-SY }
$$

12. Major Assm. Dwg. No.: H-2-821719

13. Permit/Permit Application Mo.: N/A

14. Required Response Date: $10-94$

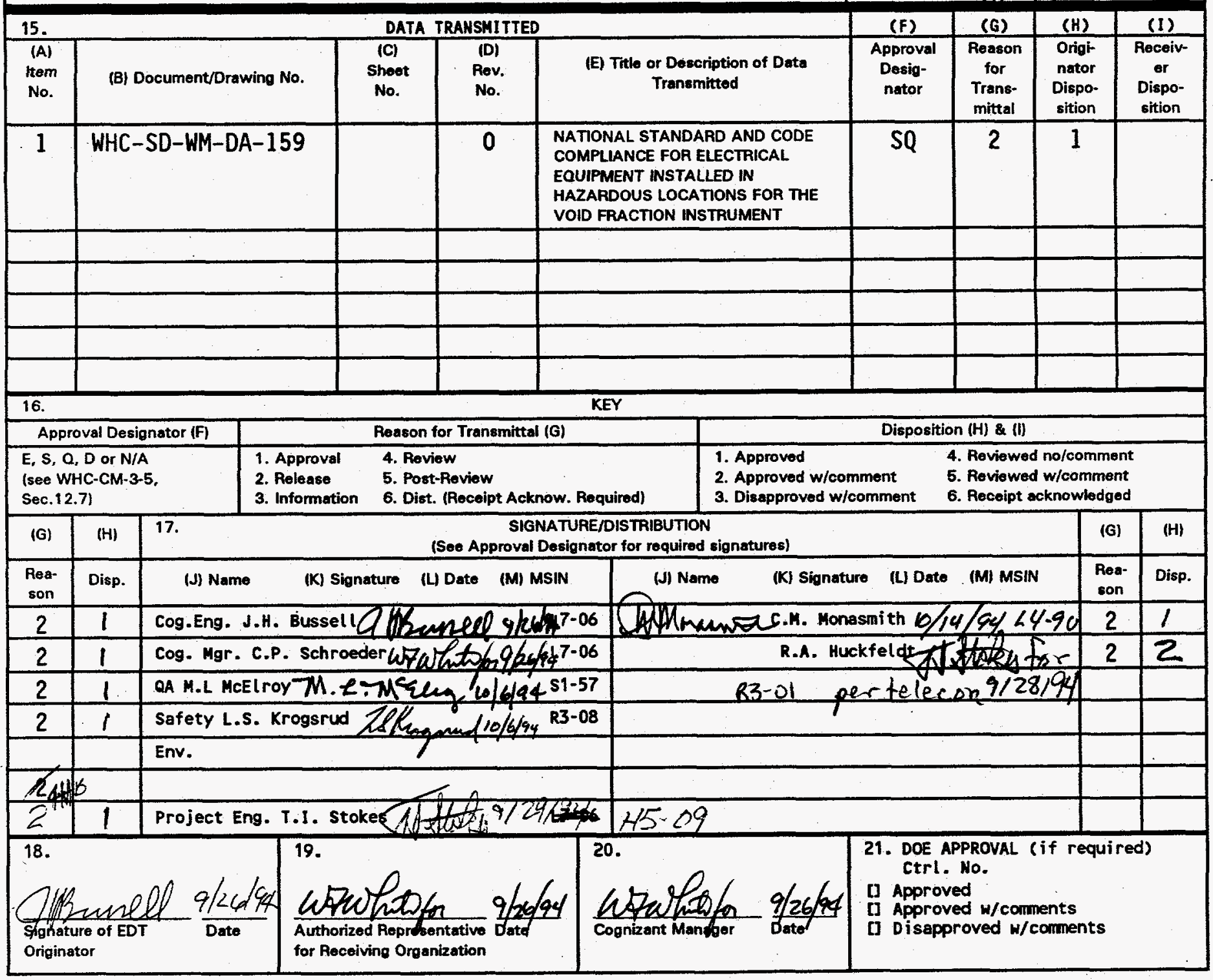




\section{DISCLAIMER}

Portions of this document may be illegible in electronic image products. Images are produced from the best available original document. 


\section{RELEASE AUTHORIZATION}

Document Number: WHC-SD-WM-DA-159, Revision 0

Document Title: $\quad$ EQUIPMENT INSTALLED IN HAZARDOUS LOCATIONS FOR THE VOID FRACTION INSTRUMENT

Release Date: $\quad 10 / 17 / 94$

This document was reviewed following the procedures described in WHC-CM-3-4 and is:

APPROVED FOR PUBLIC RELEASE

WHC Information Release Administration Specialist:

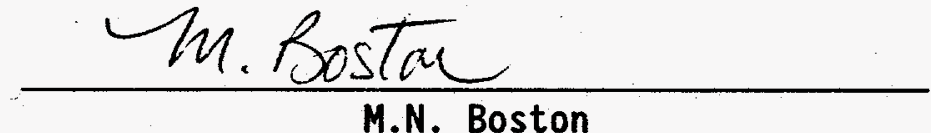

$10 / 17 / 94$

M.N. Boston

TRADEMARK DISCLAIMER. Reference herein to any specific commercial product, process, or service by trade name, trademark, manufacturer, or otherwise, does not necessarily constitute or imply its endorsement, recommendation, or favoring by the United States Government or any agency thereof or its contractors or subcontractors.

This report has been reproduced from the best ovailable copy. Available in paper copy and microfiche. Printed in the United States of America. Available to the U.S. Department of Energy and its contractors from:

U.S. Department of Energy

Office of Scientific and Technical Information (OSTI)

P.0. 80x 62

Oak Ridge, TH 37831

Telephone: (615) 576-8401

Available to the public from:

U.S. Department of Commerce

National Technical Information Service (NTIS)

5285 Port Royel Rosd

Springfield, VA 22161

Telephone: (703) $487-4650$ 
2. Title

3. Number

NATIONAL STANDARD AND CODE COMPLIANCE FOR

ELECTRICAL EQUIPHENT INSTALLED IN HAZARDOUS LOCATIONS FOR THE VOID FRACTION INSTRUMENT

5. Key Words

VFI, SY-101, Intrinsic Safety
3. Number

WHC-SD-WM-DA-159
4. Rev No.

0
6. Author

Name:JH Bussell

Atponell $9 / 26 / 44$

Organization/Charge code 7EA10/N2BH3

\section{Abstract}

The hazardous area classification is evaluated and defined for the void fraction instrument (VFI). The void fraction instrument is an instrument that is used to measure gas bubble concentration in tank waste. It is a 18.3 meter (60-foot) long pipe with swivel sampling head. The assembly is lowered into tank waste via an available riser and waste sample is obtained. The sample is obtained and the sample chamber is pressurized from a fixed volume chamber. The pressure is then measured and then the VFI is moved to the next sample elevation.

8. PUKPOSD AND bSE of DOCUnent - Tb/s document was/prepared for use fithin the U.s. bepartyent of Elergy and its cgntractops. It is to 1. be used only to perform/ direct/ or ititegrate work/under X.s. Departiont of Energy ontracts This cocument is not fporoved for publig release until feviewed.

Pateny stajes - this document cop\%, since it is transmitted ith advance or patent tlearance, is mode available in tonfidence sglely fof yos in werformape of work under contracks with the J.s. Jepartment of Engrgy. In's docyment is prt to pe published nor ito contents otheryise disstminatgd or used for parposes other then apecifieg above before patent approval for such relegse or usg has been sycured, yoon reguest, form the Prtent colnsel D.s. Depritment of Elergy Fierd offite, Righland, wh.

bISCLAIMER - This report was prepgred os an acobunt of work sponsofed by an ageney of the Uni ted states Government. Nejther tho Unjled Stazes Goyernment por any/agency/thereof/nor any of their enployees, nor any of their contractors, sublontractors or their employes, mokes any marranty, expyess or jimplied/or assynes any legh l liabj ity or pesponsjbil ity/for the tcuracy. completeness for any thirel party's luse or/the regults of such use of any tnformation, appargtus, prodlct, of process disclosed, or fepresents that /ts use woyld not inftinge privately owned rights Refergnte herein to any specific ormercjal product, pobcess, or servite by trade hame, trademapk, manufactuler, of otheryise, does not nectssarily constitute of imply ts endorsement, recoume-hdatign, or favoring by the Unitgd stayes Govetnment or any agenc/ thepeof of its ontractors or/subcont actors The yius apd opinions of authorg expressed herein do trot necessarily/state for reflect those of the United Stakes Government of any agency thereof.

9. Impact Level $\mathrm{SQ}$
10.

RELEASE STAMP

OFFICIAL RELEASE BY WHC

DATE OCT 181994

35 Station 2 
WHC-SD-WM-DA-159 REV 0

\title{
NATIONAL STANDARD AND CODE COMPLIANCE \\ FOR \\ ELECTRICAL EQUIPMENT INSTALLED \\ IN \\ HAZARDOUS LOCATIONS \\ FOR THE \\ YOID FRACTION INSTRUNENT
}

\author{
by
}

\section{J.H. BUSSELL \\ J.D. MARTIN \\ T.I. STOKES}

\section{DISCLAIMER}

This report was prepared as an account of work sponsored by an agency of the United States Government. Neither the United States Government nor any agency thereof, nor any of their employees, makes any warranty, express or implied, or assumes any legal liability or responsibility for the accuracy, completeness, or usefulness of any information, apparatus, product, or process disclosed, or represents that its use would not infringe privately owned rights. Reference herein to any specific commercial product, process, or service by trade name, trademark, manufacturer, or otherwise does not necessarily constitute or imply its endorsement, recommendation, or favoring by the United States Government or any agency thereof. The views and opinions of authors expressed herein do not necessarily state or reflect those of the United States Government or any agency thereof.

\section{$\checkmark$ September 26, 1994}


WHC-SD-WM-DA-159 REV 0

Table of Contents

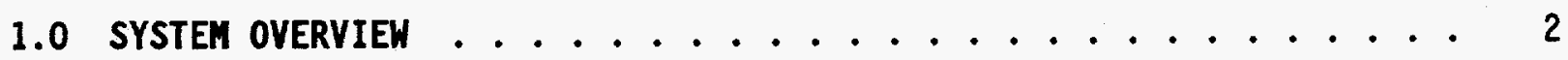

2.0 HAZARDOUS LOCATION ClASSIFICATION ............. 3

3.0 AREA CLASSIFICATION BASIS .................. 5

3.1 GENERAL . . . . . . . . . . . 5

3.2 CLASSIFICATION OF THE ENCLOSURES ON TOP OF THE VFI MAST . . . 5

3.2 .1 Interior considerations .......... 5

3.2.2 External considerations 7

3.3 CLASSIFICATION OF THE AREA INSIDE THE VOID FRACTION INSTRUMENT

MAST ..................... 8

4.0 EQUIPMENT DESCRIPTION . . . . . . . . . . . . . . 9

4.1 EQUIPMENT OF TOP ENCLOSURES . . . . . . . . . . . . 9

4.1.1 Pneumatic System Enclosure (contains pressurization chamber) ................... 9

4.1.2 Pneumatic System Enclosure . . . . . . . . 10

4.1.2 I\&C Enclosure ................. 10

4.2 Electrical Equipment and Devices in VFI Mast and Sampling Arm . 10

4.3 System Grounding ............... 10

5.0 CODE REQUIREMENTS . . . . . . . . . . . . . 10

5.1 INTRINSIC SAFETY REQUIREMENTS . . . . . . . . . . . 10

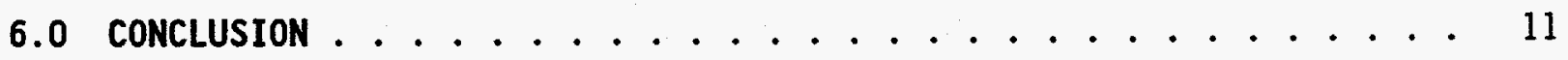

7.0 REFERENCES . . . . . . . . . . . . . . . . . 12

7.1 Reference Drawings . . . . . . . . . . 12

7.2 Documents and National standards ........... 12

7.2 Trademark Acknowledgements ............. 14

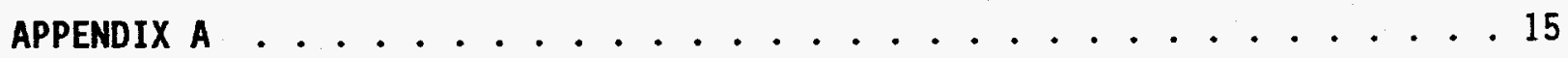




\section{WHC-SD-WM-DA-159 REV 0}

\subsection{SYSTEM OVERVIEW}

The void fraction instrument (VFI) has been developed to obtain in situ void fraction data at different elevations in waste tank 241-SY-101. A simple definition of void fraction is the volume percent of a given waste sample that is comprised of gas. Voids (gas bubbles or similar) are expected to exist in the waste tank at various elevations, at concentrations from $0 \%$ to $20 \%$ average void fraction.

The VFI is approximately a 19.8 meter (65 feet) piece of $7.62 \mathrm{~cm}$ (3-inch) schedule 80 pipe, with an arm at the bottom that is pneumatically actuated and swings out at 90 degrees from the main pipe (commonly referred to as the mast). At the end of this arm is a sample chamber. A second pneumatically controlled cylinder opens and closes the cover of this chamber. Sampling at different elevations is accomplished by lifting the VFI with a crane and lowering it into the tank through a riser. The VFI is then lowered to the desired sampling level and a sample is obtained in the sample chamber. Once a sample is captured, the sample chamber is pressurized from a fixed volume of nitrogen gas. Then pressure and temperature is measured at pressurization chamber (fixed volume gas source), along the connecting tubing, and at the sample chamber. The void fraction may be calculated after the pressure and temperature data are obtained prior to pressurizing the sample chamber and after pressurizing the sample chamber. Volume data for the pressurization chamber, the interconnecting tubing between the pressurization chamber and the sample chamber, and the sample chamber are also needed to determine the void fraction and will be determined prior to deployment.

Three enclosures are mounted to the top of the mast. The three enclosures are named the I\&C enclosure, the pneumatic system enclosure, and the pneumatic system enclosure (contains pressurization chamber). These enclosures are interconnected, and will be treated as one large enclosure. The pneumatic cylinders are remote controlled with solenoid valves. All control and measurement systems are in the enclosures as well as a heater, ventilation fans, intrinsic safety barriers (ISB), and other miscellaneous components. Drawings H-2-821718, Void Fraction Instrument Pneumatic Control Assembly, and $\mathrm{H}-2-821719$, Void Fraction Instrument Assembly, show mechanical details. Drawing H-2-821617, Void Fraction Instrument Functional Block Diagram shows the relationship between system components. Additionally, a control console is used to remotely control the system components described above. It is connected to the VFI through control and power cables.

The only electrical devices present in the mast are five $3.17 \mathrm{~mm}(1 / 8-$ inch) stainless steel sheathed MgO insulated three-wire RTDs. Three RTDs are attached to the sample chamber pressurization line at three elevations, and two RTDs extend beyond the mast bottom, but are still within sealed thermowells. In short, the RTDs never come in contact with the tank waste. 


\subsection{HAZARDOUS LOCATION CLASSIFICATION}

The waste tank 241-SY-101 produces hydrogen and other gases. At times, 1arge quantities of 'gas are released abruptly from the waste, causing hydrogen concentrations which approach, and exceed the flammable concentration levels. The hazardous area classification has been defined in WHC-SD-WM-HC-010 ReV. 1. Hazards Classification Study for the SY-101 Tank and Vicinity of 200 West - 241-SY Tank Farm.

Table 1 summarizes area classification from that document. The VFI has been designed to meet the hazard area classifications shown in table 2 . These areas are further subdivided for internal parts of the VFI and area classifications are shown in table 3.

\begin{tabular}{||l|l|}
\hline \multicolumn{2}{|c|}{ TABLE 1 } \\
Tank SY-101 Area Classification Per WHC-SD-WH-HC-010 REV 1 \\
\hline \multicolumn{1}{|c|}{ AREA } \\
\hline Liquid Waste & Class I Division 2 Group B \\
\hline Tank Vapor Space & Class I Division 2 Group B \\
\hline Pump Pit* & Nonclassified \\
\hline Tank Risers (Closed) & Nonclassified \\
\hline Tank Risers (Opened) & Cl* \\
\hline $\begin{array}{l}\text { Surface Areas above tank I, Division 2, Group } \\
\text { B }\end{array}$ \\
\hline \hline $\begin{array}{l}* \text { With proper sealing at tank interface } \\
\text { With proper gaskets and Cap bolts properly torqued. } \\
* * * \\
\text { Radius, based on specific application }\end{array}$ \\
\hline
\end{tabular}


WHC-SD-WM-DA-159 REV 0

\begin{tabular}{|c|l|l||}
\hline \multicolumn{3}{|c|}{ Hazardous Area Classification for Design Basis } \\
\hline \hline AREA & \multicolumn{1}{|c|}{$\begin{array}{c}\text { Electrical } \\
\text { Classification }\end{array}$} & \multicolumn{1}{|c|}{ Notes } \\
\hline \hline Liquid Waste & $\begin{array}{l}\text { Class I, Division 2, } \\
\text { Group B }\end{array}$ & All times \\
\hline Tank Vapor Space & $\begin{array}{l}\text { Class I, Division 2, } \\
\text { Group B }\end{array}$ & All times \\
\hline $\begin{array}{c}\text { Area immediately around } \\
\text { an open Tank Riser }\end{array}$ & $\begin{array}{l}\text { Class I, Division 2, } \\
\text { Group B }\end{array}$ & $\begin{array}{l}\text { Radius of } \\
\text { classification } \\
\text { determined case by case }\end{array}$ \\
\hline
\end{tabular}

\begin{tabular}{|c|l|}
\hline \multicolumn{2}{|c|}{ Table 3} \\
QRI Instrument Hazardous Area Classifications \\
\hline \hline AREA & \multicolumn{1}{|c|}{ Electrical Classification } \\
\hline \hline Enclosures on top of Mast & Nonclassified \\
\hline Inside of VFI Mast & Nonclassified \\
\hline $\begin{array}{c}\text { Area around decontamination spool } \\
\text { piece rubber wiper }\end{array}$ & Class I, Division 2, Group B \\
\hline Pneumatic Control Lines & Nonclassified \\
\hline Chamber Pressurizing Line & Class I, Division 2, Group B \\
\hline
\end{tabular}

The basis of the above statements will be developed in this report. Note that any location that the gas concentration can reach $25 \%$ or greater of the lower flammability limit (LFL) must be classified since this is threshold between adequate and inadequate ventilation defined by NFPA 497A and NFPA 30. 
WHC-SD-WH-DA-159 REV 0

\subsection{AREA CLASSIFICATION BASIS}

\subsection{GENERAL}

Electrical equipment and devices to be used in a classified hazardous location must be approved for that service by a nationally recognized testing 1aboratory, e.g. Underwriters Laboratory, Factory Mutua1, etc. One must not only consider the specific device, but also must consider any and all associated equipment. Associated equipment is any other equipment or device connected to, or otherwise coupled to the same wiring. Specific apparatus and wiring requirements vary with the Class I and Division 1 or 2 classification for the location specified in the National Electrical Code (NEC) Articles 500, 501, and 504.

The NEC provides for three alternative methods to prevent fire or explosions from electrical equipment operating in a classified hazardous locations. These methods are (simplified interpretations):

- Intrinsically safe apparatus: the electrical equipment/device does not store and can not provide sufficient energy to ignite a flammable mixtures -- and is approved as such.

- Purging and pressurizing of electrical enclosures: reducing either the fuel or the oxidizer, or both, to a noncombustible level and providing power cutoff switches to the equipment if purge and pressurization control is lost.

- Explosionproof enclosures and wiring methods: housing the electrical device within a qualified enclosure which will contain possible explosions due to arcing or other possible ignition sources within the enclosure. The enclosure will not allow the escape of combustion gases with sufficient temperature to ignite possible combustible gas mixtures that may present outside of the enclosure.

\subsection{CLASSIFICATION OF THE ENCLOSURES ON TOP OF THE VFI MAST}

\subsubsection{Interior considerations}

The enclosures are NEMA 4, watertight and dusttight, enclosures. The interior of the enclosures are not in direct communications with vapor space of tank 241-SY-101. The enclosures are welded together and there are large openings between the three enclosures for tubing and wire connections. These enclosures contain programmable controllers, solenoid valves, stainless steel tubing runs ( $3.17 \mathrm{~mm}$ (1/8-inch) or smaller), fans, a heater, and pressure transducers. Five tubing runs are used in the VFI. Two tubing runs (3.17 mm (1/8-inch) OD) are used for actuating the sampling arm rotation pneumatic cylinder and two tubing runs are used 
for actuating the sample chamber pneumatic cylinder. The minimum pressure in the four tubing runs is $35 \mathrm{psia}$ and the minimum pressure occurs when pneumatic cylinders are being actuated. During actuation of a pneumatic cylinder, one of the tubing runs (control lines) is pressurized with 500 psig nitrogen gas and the other tubing run is vented to atmosphere through a three-way solenoid valve and a pressure relief valve (set at $40 \mathrm{psia}$, actuates at 39 to $43 \mathrm{psia}$ ). The fifth tubing run (1.59 mm (1/16-inch) OD) connects the sample chamber to the pressurization chamber and the water tank, and it is the pressure sense line to measure the sample chamber pressure when it is pressurized from the pressurization chamber. This tubing run contains a check valve near the sample chamber.

Pressurized nitrogen gas supplied from a supply cylinder is used as the motive force for the sampling arm rotation pneumatic cylinder and the sample chamber pneumatic cylinder. Nitrogen gas, $500 \mathrm{psig,} \mathrm{is} \mathrm{also} \mathrm{used}$ to pressurize the pressurization chamber, the fixed volume of gas source. A solenoid valve is then opened to connect the pressurization chamber to sample chamber. The pressure of the pressurization chamber is measured. Then the solenoid valve is closed, disconnecting the pressurization chamber from the sample chamber, and the sample chamber is opened and the resulting pressure in the pressurization chamber and tubing run is vented into the tank waste. In the event that the tubing run, the fifth tubing run mentioned above, between pressurization chamber and sample chamber becomes plugged, it can be flushed with pressurized water supplied from the water tank. The water tank holds approximately 6.4 litres (1.7 gallons). The flushing operation is initiated by pressurizing the water tank and opening the solenoid operated valve between the water tank and this tubing run. The water from the flushing operation is exhausted into the tank waste.

Two simultaneous failures are required for the tank atmosphere to enter these enclosures through any of the five tubing runs. The first failure is line breakage or a line leak that allows waste to enter one or all of the four pneumatic or the sense lines. The second failure is the loss of a pressure boundary (e.g. solenoid valve packing seals, pressure transducer diaphragms) in the enclosures. It is unlikely that the concentration of flammable gases could approach $25 \%$ LFL in the enclosures since the duration of a gas release is short (about three minutes) and both of these failures are required to simultaneously occur for flammable gas to enter the enclosures.

The five pneumatic lines are the only hollow penetrations through the VFI mast. The inside of the VFI mast also houses five $3.17 \mathrm{~mm}$ (1/8-inch) stainless steel sheathed MgO insulated RTDs. The pneumatic lines enter the VFI mast through a $12 \mathrm{~cm}$ (5 inch) square window in the side of VFI mast above the elastomer seal. The pneumatic lines and RTDs pass through a elastomer seal just below the window. The elastomer seal is located between a lower bulkhead plate and top bulkhead plate and the elastomer is Dow Corning Sylgard 184. The VFI mast extends through the enclosures and is sealed at the top. At the top of VFI mast is the lifting ring for the VFI mast. 


\section{WHC-SD-MM-DA-159 REV 0}

The bottom of the VFI mast is seal welded. The bottom two RTDs in the VFI mast are in thermowells and are not it direct contact with the waste. The thermowells are seal welded to the bottom of the VFI mast. All five tubing penetration at the bottom of the VFI mast are seal welded to prevent waste leakage. The integrity of the tubing seal welds to bottom bulkhead of the VFI mast was verified by helium leak tests (hood method) per NTD-LT-6000 REV 3. In this test, a hood is placed around the weld being tested and filled with helium. The inside of the tubing is monitored for helium concentration to determine integrity of the weld being tested. The results and the records of the non-destructive testing are recorded in traveller VFI-002 which is on file in the 306E building. The three tubing runs, two pneumatic cylinder tubing runs and the tubing run that connects the sample chamber to the pressurization chamber; are routed through a swivel joint. Compression type tubing fittings (elbows) are used in the three tubing runs to and from the swivel joint.

\subsubsection{External considerations}

During operation of the VFI, the top enclosures will move closer to the riser flange as measurements are made at each planned sampling elevation. (The VFI is lowered by a crane.) When the VFI rests on the tank bottom, the enclosures are $45.7 \mathrm{~cm}(1.5 \mathrm{feet})$ above the decontamination spool piece rubber wiper seal. The rubber wiper provides an excellent seal on the pipe, and it is not expected to leak significantly should the tank waste release a significant quantity of flammable gases during operation. The sealing ability is not further pursued here, as a more conservative analysis has been performed and is described below. The most credible explosion hazard scenario concerning the enclosures arises when the VFI is at the lowest point of travel, $45.7 \mathrm{~cm}$ ( 1.5 feet) above the top of the rubber wiper. Los Alamos National Laboratory. (LANL) analyzed the event of a gross wiper seal leak. LANL assumes for this analys is that something causes the VFI to be fully pushed over to one side of the wiper, there by opening a crescent shaped (quarter moon) pathway past the rubber wiper seal. A large gas release in this configuration could leak flammable gases if the size of the discharge and the composition of the gas are flammable at the time of VFI mast mis-positioning. Since the flammable gases released are lighter than air, the concentration of flammable gases around the enclosures may exceed $25 \%$ of the lower flammability limit (LFL). NFPA $497 \mathrm{~A}$ and NFPA 30 implies that if the flammable gas concentration in the area exceeds the $25 \%$ LFL leve1, it must be classified as Division 2. NFPA 497A and NFPA 30 defines adequate ventilation for nonclassified area as sufficient air changes to prevent accumulation of flammable gases in excess of the LFL. For this reason; a hydrogen deflector plate was designed. This flat flange ( 2 foot diameter) is mounted $15.24 \mathrm{~cm}$ ( 6 inches) below the bottom of the enclosures, and will deflect a released gas vertical jet to the horizontal direction. This assures the enclosures are in nonclassified space even during a gas release. Extensive calculations and design analysis by LANL have been made on this disk to show that under the most severe leak described above, the flammable gas concentration is less than 25\% LFL. The design calculations and design analysis are in LAUR-92-3196 Rev. 11 Addendum 2. 


\section{WHC-SD-WH-DA-159 REV 0}

While it is true that the enclosures are within the area of an "open riser" that would normally be considered to be Class I Division 2 Group $B$, engineered safety features have been incorporated into the design that prevent accumulation of flammable gases above $25 \%$ LFL concentration. The first feature is the wiping seal that provides a seal between the VFI mast and the riser. All penetrations, the four pneumatic control lines, pressure sense lines for sample chamber, and the stainless steel sheathed Mgo insulated RTDs, into to the void fraction mast are sealed with an elastomer seal (Dow Corning Sylgard 184, a two part RTV). The elastomer seal is located between a lower bulkhead plate and top bulkhead plate. The holes for the ten penetrations in these two bulkhead plates are not sealed. A special disk is located below these enclosures that is designed to deflect and disperse any flammable gas leakage from the tank.

\subsection{CLASSIFICATION OF THE AREA INSIDE THE VOID FRACTION INSTRUMENT MAST}

The exterior of VFI mast passes through a Class I Division 2 Group. B location. The VFI mast is $7.62 \mathrm{~cm}(3-$ inch) schedule 80 pipe sections joined by welds and the pipe are welded per specification HS-V-S-013. The welds joining the sections of mast were visually inspected and inspected using a dye penetrant test. The results and records of the inspection are contained in traveller VFI-001 which is maintained in building 306E. Section 2-6 in NFPA 497A provides some guidance for requirements for a nonclassified area. Specifically in section 2-6.1 in NFPA 497A:

- Locations that are not adequately ventilated but where piping systems are without valves, fittings, flanges, and similar accessories that may be prone to leaks.

The VFI mast (outer pressure boundary) does not contain valves, fittings, flanges, or similar accessories that are prone to leak. The tubing runs for the two pneumatic cylinders (four tubing runs), and the tubing run that connects the sample chamber to the pressurization chamber are seal welded to the bottom of the VFI mast. The two RTD thermowells are also seal welded to bottom of the VFI mast. The five tubing runs in the VFI mast are not prone to leakage since the tubing sections in the VFI mast were joined by welded couplings ( $3.18 \mathrm{~mm}$ or $1 / 8$-inch tubing) or by electron beam brazing ( $1.59 \mathrm{~mm}$ or $1 / 16$-inch tubing). The welded joints and brazed joints were tested by helium leak testing as described in section 3.2.1. Section 3-3.1 in NFPA provides additional guidance:

The area should be classified if the answer to each of following questions is "Yes":

(a) Are flammable liquids or flammable gases likely to be present?

(b) Are combustible liquids likely to be handled, processed, or stored at temperatures above their flash points? 


\section{WHC-SD-MM-DA-159 REV 0}

The answer to both of these questions is no, flammable gases are not likely to be present inside the VFI mast. Flammable liquids or gases are not handled, processed or stored in VFI mast and the temperature inside of the VFI mast is less than autoignition temperature for hydrogen.

During a gas release, movement of solids in the tank (waste bergs) may break long slender components in two such as the VFI mast. Tests indicate a $7.62 \mathrm{~cm}$ (3-inch) schedule 80 pipe must undergo three cycles of bending from -45 degrees from vertical to +45 degrees from vertical before the pipe is cracked. The probability of this event happening is remote. Since consequences are high, all electrical apparatus passing internally through the VFI mast have been made intrinsically safe. The RTDs inside the VFI mast and thermowells are considered simple apparatus and are themselves intrinsically safe. The term simple apparatus as defined in ISA RP12.6 is defined to be a device such as a RTD or thermocouple that does not generate or store sufficient energy to ignite a flammable gas mixture. Transformer isolated intrinsic safety barriers are being used to isolate associated apparatus, data acquisition and indication instrumentation, from the RTD. Intrinsically safe means that a fault in the associated apparatus will not result in the ignition of a flammable gas in the hazardous location.

\subsection{EQUIPMENT DESCRIPTION}

\subsection{EQUIPMENT OF TOP ENCLOSURES}

The three enclosures on top of the VFI mast are welded to together to form an integral unit. The I\&C enclosure and pneumatic system enclosure are welded back-to-back and the pneumatic system enclosure (contains pressurization chamber) is welded to right end of assembly when facing the pneumatic system enclosure. There are numerous opening between the enclosures for tubing runs and inter-enclosure wiring runs.

\subsubsection{Pneumatic System Enclosure (contains pressurization chamber)}

The primary components in this enclosure are the pressurization chamber and a water tank. The ISB are located in the lower right corner of this enclosure. The ISB being used are Elcon Instruments mode1 1072 (dual channel). These units are transformer isolated intrinsic safety barriers and do not require grounding like zener diode intrinsic safety barriers. These ISB are approved for use in Class I, II, III, Division 1; Group A to $G$ by Factory Mutual, FM Cl. No. 3610 Entity, and for Class I, II; Division 2 Group $A$ to $D$ (certificate file no. J.I.3T3A3.AX. Three ISB are used with one spare channel. The ISB are powered from a 24 VDC power supply.

Other electrical components besides the ISB, e.g. pressure transducers, RTDs, level transducers, solenoid valves, etc., in this cabinet are not 
in general approved for use in hazardous locations. This enclosure is located in a nonclassified location.

\subsubsection{Pneumatic System Enclosure}

The primary components in this enclosure are the solenoid valves that control the actuation of the sampling arm rotation pneumatic cylinder and the sample chamber pneumatic cylinder, pressure sensors, and a cabinet heater.

Electrical components, pressure transducers, solenoid valves, etc., in this cabinet are not in general approved for used in hazardous locations. This enclosure is located in a nonclassified location.

\subsubsection{I\&C Enclosure}

The primary components in this enclosure are the data acquisition and the data communication system. An Acromag 4300 series data acquisition system is being used for data acquisition.

\subsection{Electrical Equipment and Devices in VFI Mast and Sampling Arm}

The RTDs are the only electrical devices that are located in or pass through the VFI mast. No other electrical devices are located in this area. The sampling arm does not contain any electrical devices

\subsection{System Grounding}

The ISB do not require grounding. However, for personnel safety and compliance with the NEC, the enclosures and the mast are grounded through a separate grounding conductor. The enclosures and the mast are bonded together by an equipment grounding conductor. The grounding conductor is connected to a tank riser. The tank riser is considered to be most effective grounding electrode available when used with an approved grounding clamp.

\subsection{CODE REQUIREMENTS}

\subsection{INTRINSIC SAFETY REQUIREMENTS}

Factory Mutual is the nationally recognized testing laboratory that certified that the ISB are intrinsically safe if installed in accordance 


\section{WHC-SD-WM-DA-159 REV 0}

with the manufacturer's control drawing. ANSI/UL-913-1988 is only used to provide guidance for establishing good installation practices.

ISA RP12.6, Installation of Intrinsically Safe Systems for Hazardous (Classified) Locations, provides the installation requirements for intrinsic safety of instrumentation in hazardous environments. The NEC refers users of the Code to this ISA Standard

ANSI/UL-913-1988, Intrinsic Safe Apparatus and Associated Apparatus for Use in Class I, II, and III, Division 1, Hazardous Locations, specifies the design criteria for the equipment, the installation wiring requirements and the testing requirements used by testing laboratory to assure the instruments do not release sufficient energy to ignite a hydrogen mixture.

The design uses ISB to limit the normal or accidental electrical potential on the instruments in the VFI mast and thermowells. The detailed installation requirements are shown in Appendix $A$, Intrinsic Safety Design Review Checklist.

\subsection{CONCLUSION}

All the hazardous classifications for the VFI have been determined as specified in table 3 . The area inside and outside the enclosures above deflector plate are nonclassified. This is possible by the use of a deflector plate and providing several barriers to gas entry into the electrical enclosures. The area under the deflector is Class I Division 2 Group B.

The RTDs are the only electrical device in the VFI mast, and are intrinsically safe. The intrinsically safety requirement assures that no spark hazard is present in waste tank 241-SY-101 (or other similar waste tank) even under the postulated event of the VFI mast breaking in to two or more pieces. 


\section{WHC-SD-WH-DA-159 REV 0}

\subsection{REFERENCES}

\subsection{Reference Drawings}

H-2-821718, Void Fraction Instrument Pneumatic Control Assembly

H-2-821719, Void Fraction Instrument Assembly

H-2-821617, Void Fraction Instrument Functional Block Diagram

\subsection{Documents and National Standards}

ANSI/ISA RP12.6, Installation of Intrinsically Safe. Systems for Hazardous (Classified) Locations, 1987, Instrument Society of America.

ANSI/UL-913-1988, Standards for Intrinsically Safe Apparatus and Associated Apparatus for Use In Class I, II and III, Division I Hazardous (Classified) Locations, 1988, Underwriters Laboratory.

Instruction Manual No. 063 2A16, Instruction Manual Types 1011/12 - 1061/62 1071/72 Signal Converters, Elcon Instruments.

NEMA 250-1985, Enclosures for Electrical Equipment (1000 volts maximum) National Electrical Manufacturers Association.

NFPA 70-1993, National Electrical Code (NEC), National Fire Protection Association.

NFPA 497A, Recommended Practice for Classification of Class I Hazardous (Classified) Locations for Electrical Installations in Chemical Process Area, 1986.

NFPA-497M-1991, Manual for Classification of Gases, Vapors, and Dusts for Electrical Equipment in Hazardous (Classified) Locations, National Fire Protection Association.

NFPA 30-1990, Flammable and Combustible Liquids Code, National Fire Protection Association.

Hauptman, J. P., Sisk, J. J., Welding of Stainless Steel and Nickel Alloy Structural and Other Components REV A., HS-V-S-0013, Westinghouse Hanford Co., October 2, 1992.

Meriman, R, et. al., Hazards Classification Study for the SY-101 Tank and Vicinity of 200 West -- 241-SY Tank Farm, WHC-SD-WM-HC-010 REV 1, Westinghouse Hanford Co., March, 1994. 


\section{HHC-SD-WM-DA-159 REV 0}

Unal, C, A Study of Freejet Around The Voidmeter Instrumentation Box to Determine NEC Classification of the Voidmeter, LAUR-92-3196 Rev. 11 Addendum 2, Los Alamos National Laboratory, 1994.

WHC-CM-4-38, Nondestructive Examination Procedure, NDT-LT-6000 REV 3, Westinghouse Hanford Co., January 15, 1994. 


\section{WHC-SD-WM-DA-159 REV 0}

\subsection{Trademark Acknowledgements}

ANSI is a registered trademark of American National Standards Association, Inc.

Elcon, and Elcon Instruments is a registered trademarks of Elcon Instruments, Inc.

FM, and Factory Mutual, are registered trademarks of Factory Mutual Research Corporation.

National Fire Protection Association, NFPA, National Electrical Code, and NEC are registered trademarks of the National Fire Protection Association.

ISA, and Instrument Society of America are registered trademarks of the Instrument Society of America.

UL, and Underwriter's Laboratory are registered trademarks of Underwriter's Laboratories, Inc.

NEMA is a registered trademark of National Electrical Manufactuerers Association

Dow Corning, and Sylgard 184, are registered trademarks of Dow Corning Corporation. 


\begin{tabular}{|c|c|c|c|c|c|c|c|c|c|c|c|}
\hline \multirow{3}{*}{$\begin{array}{l}\text { Dovicel } \\
\text { Slignal } \\
\text { Line }\end{array}$} & \multicolumn{11}{|c|}{$\begin{array}{c}\text { Table A-1 } \\
\text { Verification of Entity Approval Parameters }\end{array}$} \\
\hline & \multirow[b]{2}{*}{ 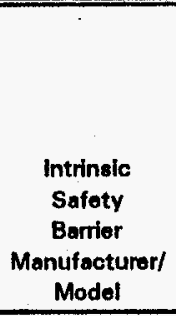 } & \multirow{2}{*}{$\begin{array}{c}\text { Associated } \\
\text { Apparatus/ } \\
\text { Control Room } \\
\text { Apparatus } \\
\text { Maximum Input } \\
\text { Voltage }\end{array}$} & \multirow[b]{2}{*}{$\begin{array}{l}\text { Cable } \\
\text { Length }\end{array}$} & \multicolumn{2}{|c|}{ Cable Parameters } & \multicolumn{2}{|c|}{$\begin{array}{l}\text { Total Cable } \\
\text { Impedance }\end{array}$} & \multicolumn{2}{|c|}{$\begin{array}{c}\text { Barrior } \\
\text { Impodance } \\
\text { Llmits }\end{array}$} & \multirow{2}{*}{ 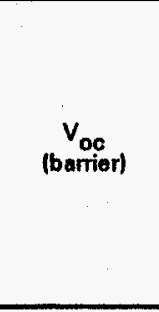 } & \multirow{2}{*}{ (bantior) } \\
\hline & & & & Cap./ft & Ind./ft & Cap. & Ind. & Cap. & Ind. & & \\
\hline $\begin{array}{l}\text { RTD (TE-5, 6, } \\
7,8, \& 9)\end{array}$ & $\begin{array}{l}\text { Elcon } \\
1071\end{array}$ & $<250$ VRMS & $70 \mathrm{ft}$ & $60 \mathrm{pF}$ & $0.2 u \mathrm{H}$ & $4200 \mathrm{pF}$ & $14 \mathrm{uH}$ & $1.1 \mathrm{uF}$ & $47 \mathrm{mH}$ & $13.1 \mathrm{~V}$ & $26 \mathrm{~mA}$ \\
\hline & & & & & & & & & & & \\
\hline & & & & & & & & & & & \\
\hline & & & & & & & & & & & \\
\hline & & & & & & & & & & & \\
\hline & & & & & & & & & & & \\
\hline & & & & & & & & & & & \\
\hline & & & & & & & & & & & \\
\hline & & & & & & & & & & & \\
\hline & & & & & & & & & & & \\
\hline $\begin{array}{l}\text { Note: } \\
\text { 1. Whon cablo paramete } \\
\text { 2. W/8-inch threo condu unt } \\
\text { 3. Maximum cablo longt } \\
\text { Outdoor environmental. }\end{array}$ & $\begin{array}{l}\text { onot known } \\
\text { MoO cablo is } \\
\text { Mo used to cal } \\
\text { itlons at Hant }\end{array}$ & $\begin{array}{l}\text { those values: Cape } \\
\text { no used. } \\
\text { ate cable capacitan } \\
-20^{\circ} \mathrm{F} \text { to }+120^{\circ}\end{array}$ & itance - 60 & fit, Ind & .0 .0 .2 & it sectil & ISA RP12. & & & & \\
\hline
\end{tabular}




\begin{tabular}{|c|c|c|}
\hline $\begin{array}{l}\text { ISA RP1 } 2.6 \\
\text { Section }\end{array}$ & Section Requirement & $\begin{array}{l}\text { Yes/ } \\
\text { Nol } \\
\text { NA }\end{array}$ \\
\hline 4.3.2 & $\begin{array}{l}\text { Mutticonductor cable sealing or venting between classified divisions to prevent transmission of flammable gases. } \\
\text { Notes: } \\
\text { Seals may not be required unless there is pressure drop across cable that would transport gas. This would exist if the } \\
\text { cable with terminated in a pressurized explosionproof enclosure. } \\
\text { Wires larger than } 2 \text { AWG may pass considerable gas through the strand interstices. } \\
\text { Wires may be sealed by using a butt splice with a crimp or compression termination. The butt splice creates a gas tight } \\
\text { seal. } \\
\text { A cable must not pass more than } 198 \mathrm{~cm}^{3} / \mathrm{hr} \text { at a pressure of } 1493 \text { pascals pressure difference across cable } 10.007 \\
\mathrm{ft}^{3} \text { hr at } 6 \text { inches of water column). } \\
\text { If this is a problem this outer jacket of the cable should be removed when paseing through seal fitting where a conduit } \\
\text { seal is made. }\end{array}$ & Yes \\
\hline \multicolumn{3}{|c|}{$\begin{array}{l}\text { MgO cable is used for RTDs. An elastomer seal is used to seal the top of the VFI mast. Wiring methods do not need to be explosion proof since intrinsically } \\
\text { safe electrical apperatus is being used in hazardous locations. }\end{array}$} \\
\hline 4.3 .3 & Conduit or raceway sealed or vented between classified divisions to prevent transmission of flammable gases. & NA \\
\hline 4.3.4 & $\begin{array}{l}\text { Cable or wiring chosen to meet the requirements of device control drawing. i.e. capacitance, inductance, insulation } \\
\text { resistance. }\end{array}$ & Yes \\
\hline 4.4 .1 & $\begin{array}{l}\text { Intrinsically safe wiring cables, and raceways are clearly identified and separated from nonintrinsically safe wiring (such } \\
\text { as power wiring. Permissible methods: (1) separate raceway; (2) positively enclosed in an onclosure or cable tray, } \\
\text { separated in cable tray from nonintrinsically safe wiring by insulating or orounded partitions; (3) intrinsically safe wiring } \\
\text { separated } 50 \mathrm{~mm} \text { (1/2-inch) from nonintrinsically safe wiring and positively secured (tied down) }\end{array}$ & Yes \\
\hline \multicolumn{3}{|c|}{$\begin{array}{l}\text { Intrinsically safe wiring cables consist of three conductor cables for the five RTDs. The outside of each RTD cable is sheathed with a stainless steel mesh. } \\
\text { Tags have been placed on the cables to identify the cables as being intrinsically safe. A differential pressure transducer is located close to the wiring on } \\
3 / 4 \text {-inch standoffs. The outer case of the differential pressure transducer is metal thus satisfying the requirements of } 2 \text {. }\end{array}$} \\
\hline 4.4 .2 & Does wiring in panel or enclosures meet the same criteria as 4.4 .1 above. & Yes \\
\hline \multicolumn{3}{|c|}{ Metal sheathed mineral insulated $(\mathrm{MgO})$ used for intrinsically safe wiring. } \\
\hline 4.4 .3 & Intrinsically safe and nonintrinsically wiring shall not be mixed in the same connector. & NA \\
\hline 4.4.4 & $\begin{array}{l}\text { If plug and socket connectors are used to connect intrinsically safe circults, intrinsically safe circuit connectors shall not } \\
\text { be interchangeable with nonintrinsically safe connectors. }\end{array}$ & NA \\
\hline 4.5 .1 & $\begin{array}{l}\text { Associated apparatus and control room apparatus connected to it shall not be powered by more than } 250 \mathrm{~V} \text { (ms or dc, } \\
\text { line-to-line or line-to-ground) and shall not generate any voltages in excess of } 250 \mathrm{~V} \text {. Note: there is exception is the } \\
\text { associated equipment has specifically designed for higher voltages.) }\end{array}$ & Yes \\
\hline 4.5 .3 & $\begin{array}{l}\text { Associated apparatus (barriers, instruments) installed in hazardous (classified) location must be protected for the } \\
\text { hazardous (focation) location. I.E. explosion proof housing. purging, or intrinsic safety practice }\end{array}$ & Yes \\
\hline
\end{tabular}




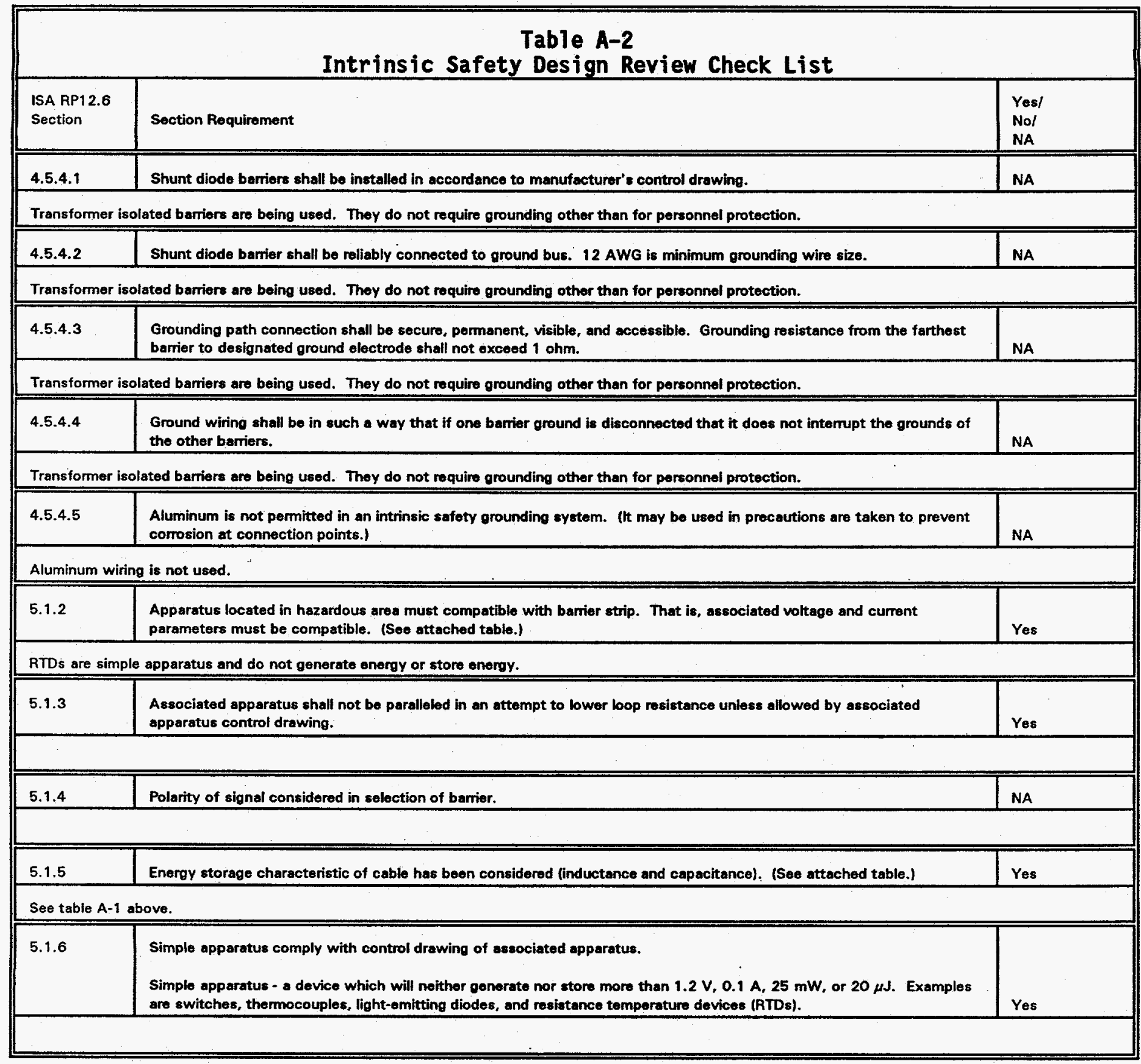




\section{WHC-WM-DA-159 REV O \\ APPENDIX A}

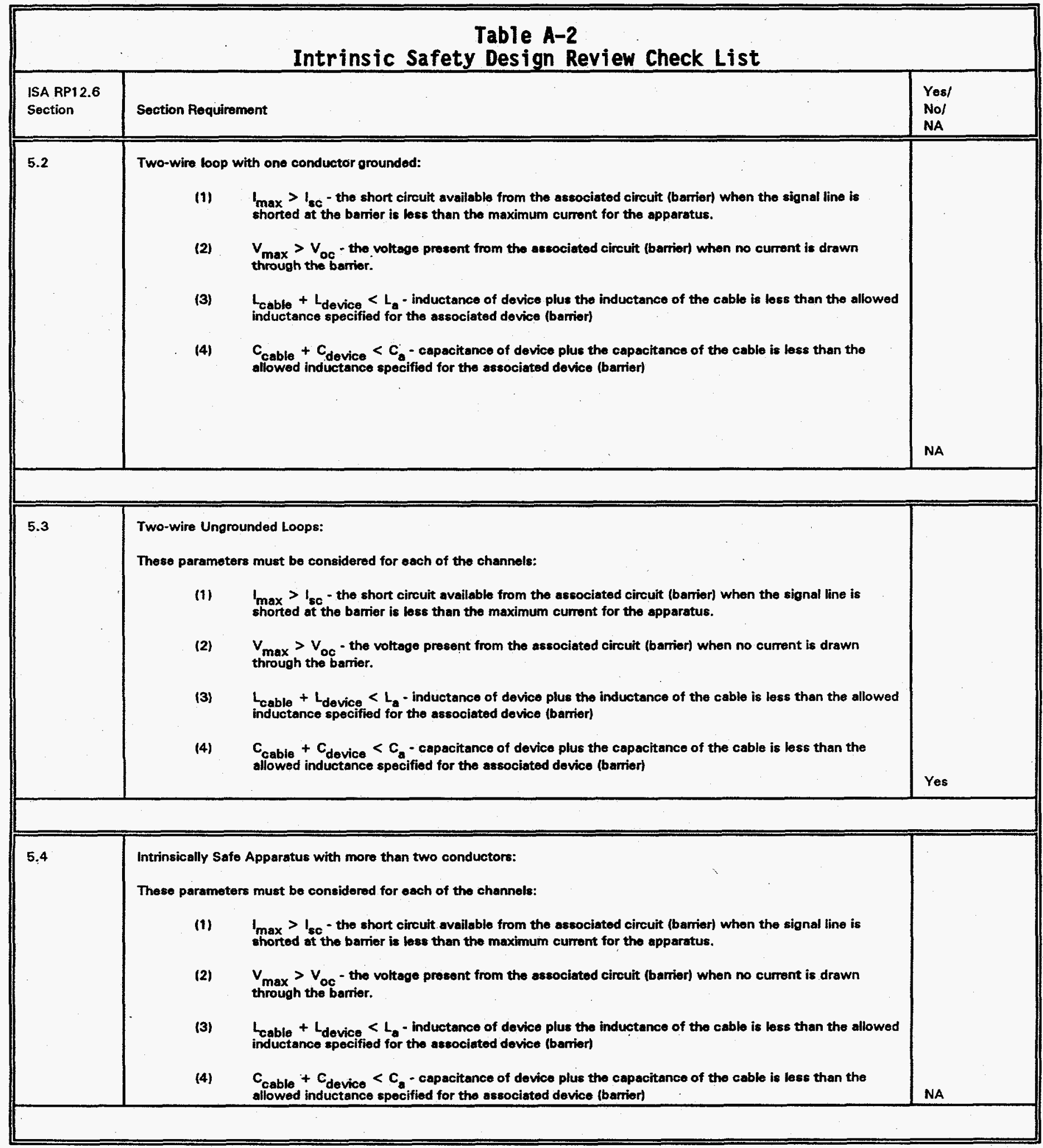




\section{WHC-WH-DA-159 REV 0 \\ APPENDIX A}

\begin{tabular}{|c|c|c|c|}
\hline \multicolumn{4}{|c|}{$\begin{array}{c}\text { Table A-2 } \\
\text { Intrinsic Safety Design Review Check List }\end{array}$} \\
\hline $\begin{array}{l}\text { ISA RP1 } 2.6 \\
\text { Section }\end{array}$ & Section Requirement & & $\begin{array}{l}\text { Yest } \\
\text { Nol } \\
\text { NA }\end{array}$ \\
\hline 5.5 & $\begin{array}{l}\text { Intrinsically Safe App } \\
\text { These parameters mi } \\
\text { (1) (3) } \\
\text { (4) } \\
\text { (5) } \\
\text { cault conditions mus }\end{array}$ & 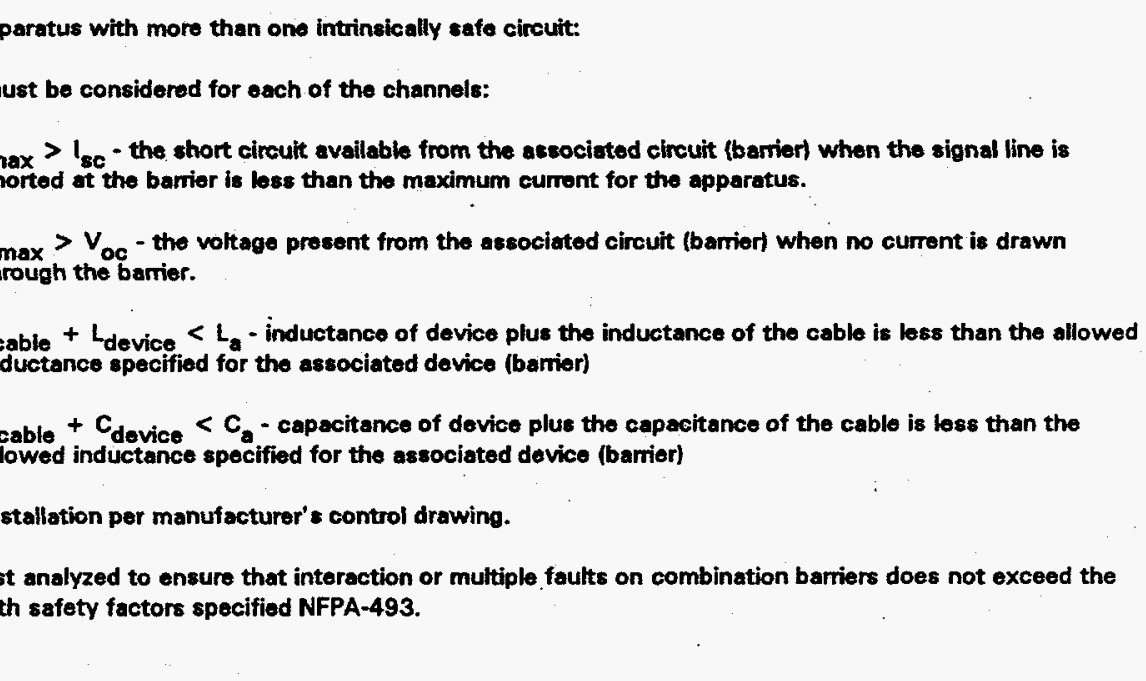 & 列 \\
\hline
\end{tabular}

